\title{
The Impact of Virtual Writing Tutor on Writing Skills and Attitudes of Omani College Students
}

\author{
Amal Aamir Al Badi ${ }^{1}$, Mohamed El Tahir Osman² \& Abdo, M. Al-Mekhlafi ${ }^{2}$ \\ ${ }^{1}$ Instructional Developer, Virtual Learning Environment Department, Military Technological College, Oman \\ ${ }^{2}$ Department of Instructional \& Learning Technologies, College of Education, Sultan Qaboos University, \\ Sultanate of Oman \\ Correspondence: Mohamed El Tahir Osman, Associate Professor of Educational Technology, Department of \\ Instructional \& Learning Technologies, College of Education, Sultan Qaboos University, Al Khod, 123, \\ Sultanate of Oman. Tel: 968-9516-4286.
}

Received: November 7, 2020

Accepted: December 12, 2020 Online Published: December 30, 2020

doi:10.20849/jed.v4i3.828

URL: https://doi.org/10.20849/jed.v4i3.828

\begin{abstract}
The present study aimed to examine the impact of Virtual Writing Tutor (VWT) software on the academic writing skills of Year 1 Omani EFL students in the College of Applied Science, (CAS)-Sohar and their attitudes towards using VWT software to enhance their academic writing skills. The sample consisted of 35 students in the control group and 35 in the experimental group (Total $\mathrm{N}=70$ ) who were enrolled in the English for Academic Purposes (ENAP1002) course at CAS-Sohar. The data collection tools included pre-test and post-test for the two groups, and attitude scale for the experimental group. The findings of the study showed a positive large effect size (Cohen's $d=0.88$ ) of VWT on writing skills. In addition, Year 1 students in the experimental group enjoyed using the VWT software and found it beneficial and helpful in checking the accuracy of their essays including spelling, punctuation, grammar and vocabulary. In light of the research findings, implications and recommendations for future research were outlined.
\end{abstract}

Keywords: virtual writing tutor, writing skills, EFL learners, attitudes

\section{Introduction}

The teaching of the English language in the Omani HEIs has received increasing emphasis in recent years as students usually start with an English language foundation programme to foster their English language skills before proceeding to their specializations. In addition, there are many degree programmes that are taught entirely in English. Hence, acquiring a good level of English is necessary particularly in HEIs where it is the medium of instruction, as is the case in most fields of specialization in BA and MA degrees.

Students admitted into the foundation programme of the Colleges of Applied Sciences (CAS) are required to sit an English placement test at the beginning of the first semester. In light of their performance on the test, they are streamed into four levels A (advanced level), B, C, and D (beginner level). Streaming students into these four levels is helpful in determining skills that require improvement and in planning teaching methods and instructional materials for each level. The duration of the foundation programme is two to four semesters before students move to Year 1. In Year 1, students start their specializations, in which they attend two courses on English for Academic Purposes (EAP1 and EAP2).

Learning and teaching English as a foreign-language (EFL) necessitates great attention on writing skills for college students, especially, non-native speakers such as Omani students (Adnan, 2009). To develop these writing skills, EFL writing in particular and EFL teaching and learning in general have benefited from and are shaped by trends in instructional and learning technologies.

\subsection{Problem Statement}

Researchers (Al Badwawi, 2011; Al Issai, 2012) stated that like their colleagues in other Omani HEIs, instructors in other CAS campuses face problems with the level of students' writing. Additionally, it was observed that although students take the general foundation programme prior to streaming into their majors in the college, they continue to struggle in academic writing as was apparent in their projects and end of semester exams. It is needless to say that writing skills are necessary for academic success and, thus, college students need to continue 
developing their writing skills after the English foundation programme. Previous research provided empirical evidence for the pedagogical impact of technologically-enhanced learning environments on developing students' academic writing skills (Al Naibi et al., 2018; Atashian \& Al-Bahri, 2018; Bernacki, Aguilar, \& Byrnes, 2011; Harris, Lindner, \& Pina, 2011; Mosquera, 2017; Sliger et al 2017; Stapleton, 2010). Nonetheless, the literature has not been conclusive on the impact of the various types and attributes of online learning and virtual learning environments, particularly in the area of language learning. It is hoped that this study will contribute to the scarce literature in this area, and at the same time carry the debate further on the role and impact of virtual tutoring in language acquisition in general, and academic writing in particular.

\subsection{Purpose and Research Questions}

This study had two main objectives. First, it aimed to study the impact of Virtual Writing Tutor software on the academic writing skills of Year 1Omani EFL students in College of Applied Sciences-Sohar (CAS-Sohar). Second, it aimed to determine the attitudes of Year 1 Omani EFL students in College of Applied Sciences-Sohar towards using the Virtual Writing Tutor software to improve their academic writing skills.

Therefore, this study attempts to answer the following research questions:

- What is the impact of the Virtual Writing Tutor software on the writing skills of Year 1 students in College of Applied Sciences -Sohar?

- What are the attitudes of Year 1 students in College of Applied Sciences -Sohar towards the use of the Virtual Writing Tutor software for improving writing skills?

\subsection{Definition of Terms}

The following terms were commonly used in this study:

Virtual Writing Tutor: refers to online virtual writing software used by ESL/EFL students and instructors for developing and proofreading writing skills synchronously and asynchronously.

In this study, it referred to online writing software that was used to assist writing composition through the use of automated electronic feedback on the students' essay writing.

Writing Skills: Urquhart (2006, p.33) stated that "writing is a recursive process, which means students revise throughout the process, frequently moving back and forth among the different stages". Recently, Hayes (2012) defined writing as a mental activity or process resulting from the interactions of multiple cognitive sub-processes that a writer implements to generate, express, and refine their ideas while formulating a text.

In this study, it referred to a demonstration of a proper academic writing which involves a development of a student's ideas and thoughts on a specific topic in a written format with a clear organization of ideas, and an appropriate content taking grammar and vocabulary into consideration.

\subsection{Literature Review}

\subsubsection{Conceptual Framework of Academic Writing}

According to Flower and Hayes (1981, p. 369) academic writing is considered as "a process of forming opinions and making choices, with various opinions about the directing forces governing the writer's thinking process, ranging from the writing's purpose, topic, situation, and audience to syntactic structures and lexical access". Academic writing requires the students to collect information related to different subjects from different sources and then reproduce this information into a new piece of writing (Ezer, Margolin \& Sagi, 2009). According to Myhill and Watson (2011), the pedagogy for writing needs to draw on the perspective of cognitive psychology, socio-cultural theory and linguistics that establish the theoretical frameworks for writing research studies. Therefore, a sound pedagogical writing approach is formed by a holistic theoretical basis that includes all of the three mentioned perspectives; cognitive psychology, socio-cultural theory and linguistics perspective (Al Badwawi, 2011).

When Grade 12 students leave school and join HEIs, they experience a very new culture differing completely from that of the school environment since the former has its own demands and methods needed for academic surviving. That is to say, Year 1 students need to acquire new literacy practices so that they can function effectively in the context of HEIs. Hyland (2009) believed that HEIs emphasizes academic writing since learning and teaching process takes place through written language. Some research studies (Bacha \& Bahous, 2008; James, 2016) have emphasized that essay writing is the most common assessment method in higher education as it shows students' academic success in various fields including Humanities, Social Sciences, Engineering and Medicine, to name but a few. Likewise, Year 1 students gain a deeper understanding of their specializations 
through reading writings related to their disciplines before lecturers ask them to compose academic assignments and projects representing improvements in their knowledge. Academic writing is essential not only for English-major students but also for students specialized in various majors. With the basic premise that blending technology in language teaching will be beneficial for Engineering and IT students, James (2016) conducted an experimental study involving a class of 26 Omani post-foundation learners for a period of one semester in both Engineering and IT specializations. He explored how ICT tools such as WebQuest, Quizlet Quiz, and Blog can be integrated in the teaching of academic writing. The findings indicated a positive impact of these tools on students' academic writing. The study recommended careful blending of emerging technologies in teaching to improve the learner's performance in a more stimulating and creative manner.

Although academic writing is critical for students' college survival, it is important to point out that it is one of the most challenging skills to develop as it entails both knowledge of the subject-matter (specializations) and knowledge of language use. Therefore, the development of academic writing is essential since it is embedded into the curriculum of the disciplines and is premeditated to fit the diverse subject areas as a means of improving students' performance in that discipline (Al Badwawi, 2011). Manchón and Larios (2007) indicated that developing academic writing in the first year in college helps students to make meaningful writing experiences. Moreover, it can help them to put into practice what they learn in their subject courses (Ellis, 2004), because they use their writing to summarize information, organize text, and think critically (Bacha, 2002). Finally, Academic writing can reinforce the second language learning since students it can improve their second language learning because when students write, they are involved in processing linguistic problems as Manchón and Larios (2007) asserted.

Research findings have shown a strong correlation between learners' academic achievements in HEIs and their academic literacy skills. Cohen-Gross (2003) proposed that academic writing skills are viable predictors of high performance during the first year of college. Ellis et al. (2007) studied undergraduate biology students' perceptions of writing. They found that students' conception of and approaches to writing were affected by their previous writing experiences of positive perceptions about the importance of academic writing in understanding their majors.

\subsubsection{Technology and English Language Education}

Technology integration in education is evolving at a rapid speed, and consequently, changing conventional ways of learning and teaching (Metin et al., 2012). It is believed that technology-based instruction can qualify of the teaching and learning experience. Research indicates an exponential increase in technology integration in education general, and in language-learning in particular such as blogs, electronic portfolios, mobile learning applications, online dictionaries, video conferencing, webinars and wikis (Altun, 2015; Chun et al., 2016; Cohen-Gross, 2003; Haines, 2016; Healey, 2018).

The relevant literature shows several positive impacts of technology integration into English language education. First, language-learning technologies have undoubtedly made a great contribution to the language learning process by providing unlimited valuable resources for learning and teaching. Cetto (2010) stated that technology extended the interaction and empowered students' learning experience by offering them better chances to use the language. More importantly, teaching by using conventional approaches is no longer inspiring for today's young digital generation. Learners want more interaction and learning outcomes bring about efficient results when they are engaged in the target language by using modern instructional technology (Altun, 2015). Moreover, language technology tools encourage communication, collaboration, and social networking which lead to positive outcomes and satisfaction for both teachers and learners (Odera and Ogott (2014). Research evidence suggests that integrating technology in language instruction leads to not only positive outcomes and satisfaction, but also affects the attitudes of students and teachers. According to Orgaz et al. (2018) learners' attitude toward technology influenced their perception about technology, and their attitude toward social networks had a positive influence on the use of technology. In contrast, teacher attitudes toward using technology might differ from those of students, and, thus, the technology integration process is particularly critical when teachers are considered. Baturay et al. (2017) investigated the relationship among preserve teachers' computer competence, their attitude towards computer-assisted education, and intention to use technology. The results revealed that ownership of computer, access to Internet and amount of daily use of the computer do not correlate with attitude towards computer-assisted education.

Technology tools support English language teaching in a more multimodal setting where learners enjoy greater achievement and independence, and have more positive attitudes towards producing language through digital forms. Blake (2016) summarized the facets of technology integration in English language skills; reading, writing, 
speaking, and listening. First, listening and speaking skills can help integrate technology faster than other skills. Due to advances in technology tools, speaking tasks may encompass listening and writing as well, as students develop and post their videos. Apparently, emergent technologies have shifted the conventional art of oral storytelling to digital storytelling. Abdelmageed and El-Naggar (2018) looked at the impact of digital storytelling on students' oral proficiency and their satisfaction with the digital storytelling learning experience. The findings of the study with first-year college students disclosed that there was a statistically significant effect on students' oral proficiency and satisfaction.

Listening, on the other hand, might entail reading captions, reflecting on cultural differences and good performance in speaking. Hwang et al. (2016) examined the viability of mobile game-based learning activities. The findings showed that while listening performance of the two groups was equal on post-test, the students in the experimental group outperformed their counterparts in the control group on the verbal post-test. The findings also showed that most participants had positive perceptions toward activities that are supported by a mobile system. The findings indicated that game-based instruction can enhance students' speaking skills significantly. Furthermore, Hwang et al. (2016) highlighted that students' engagement in learning activities via a mobile system encourage EFL students to practice their speaking English skills more frequently. It also allows them to create meaningful sentences in an authentic context, and speak with more accuracy and greater confidence.

Third, regarding reading skills and technology, Lassault and Ziegler (2018) stressed that digital technology can offer "first-aid" solutions for training reading skills within the school environment well before children fall behind. The advancement in technology and the amount of individual usage of these technological tools can positively influence the achievements of students. Similarly, Huang and Hong (2016) examined the impact of a flipped English classroom treatment on high school students' English reading comprehension in Taiwan. The findings showed that students' reading comprehension improved significantly during the treatment.

Finally, considering the role of technology in improving writing skills, writing can be practiced in systematic stages that leverage collaborative chatting, blogs, and repeated negotiations of their linguistic proficiency. Thus, technology affords spaces for language learning and teaching. Nonetheless, academic writing, as the most complex skill among the four language skills, has received more attention from a number of researchers in the field (Godwin-Jones, 2015; Sauro, 2014, Kramsch, 2009) and is further discussed in the next section.

\subsubsection{Technology and Writing Skills}

Technology in Writing Skills: there is a growing tendency towards increasing learners' autonomy in the writing skills through effective feedback and reflective learning (Denton et al., 2008). It is apparent that acquiring good writing skills can be a fundamental contributor to improved English language proficiency of Year 1 college students. Chun (2016) summarized a number of emerging technologies that are being designed and employed mainly for developing English language skills in general, and writing skills in particular. These technology tools include, but not limited to drill and practice, web-based peer reviews, and automated essay scoring. The utilization of technology tools such as word processing, computer writing systems, e-portfolio, blogs, grammar checkers, and other related computer-assisted writing software has increased both the quantity and quality of students' writing compared to conventional teaching methods (Chun, 2016; Rosen, 2016). Accordingly, it can be argued that creating a productive learning environment for writing to flourish in is the key factor for the success of technology in developing writing skills.

Recent studies on the impact of using technology to improve students' writing skills have significant findings in terms of academic writing and students' attitudes towards technology integration. Xu et al. (2018), for example, analyzed 21 independent studies from 16 publications and found that technology integration have a considerable effect size on writing skills in comparison to conventional instructional methods. Additionally, Jayaron and Abidin (2015) conducted a quasi-experimental study with 28 diploma level learners. The study investigated the effectiveness of using Moodle Forum on students' writing output considering the language units, clauses and the number of the words. The analysis of quantitative and qualitative data indicated that the intervention of Moodle Forum had significantly impacted on the participants' EFL writing. However, in order for this successful integration to take place, Reichelt (2001) stressed that describing all necessary directions and requirements for students clearly before their engagement with technology is very essential.

Students' attitude towards using instructional technology in developing writing skills is as important as academic achievement. Their attitudes and perceptions toward using certain technology in teaching and learning writing can affect the future implementation of these instructional technologies. Metin et al. (2012) cited various research studies (Pala, 2006; Yavuz \& Coskun, 2008; Can, 2010; Kurbanoglu \& Onder, 2010) that illustrated a positive attitude towards instructional technology in education in general. Recently, Khan, et al. (2018) 
implemented Desire2Learn (D2L) didactic software for teaching subject-verb agreement at Al-Majma'ah University in Saudi Arabia. The findings of their study showed that the students in treatment group outperformed their counterparts in the control group. Moreover, students showed a positive attitude towards using D2L software in EFL learning. Similar positive attitudes were also accomplished by using weblogs to develop writing skills. Aljumah (2012) conducted a study with 35 Saudi students majoring in English to investigate their attitudes toward the use of blogs in learning writing, and to demonstrate the advantages and disadvantages of using blog in language learning. Responses to the attitude scale indicated that students have a favorable attitude towards weblog use in the classroom. The findings of his study suggested increased interest and motivation to use English because of interaction with, and feedback from classmates and teachers are the advantages of using blogs as perceived by the students.

Local studies have also provided strong evidence for the impact of online technologies on writing skills. Jayaron and Abidin (2016) conducted a study to determine the effectiveness of online forum discussions on learners' EFL writing performance in terms of its linguistic complexity. 56 learners at post-foundation level from Al Musanna College of Technology in Oman participated in the study. While the experimental group $(\mathrm{N}=28)$ was involved in a synchronous online forum discussion, the control group $(\mathrm{N}=28)$ was engaged in asynchronous blog writing for a period of one semester. The findings illustrated that the use of online forum discussions in facilitating EFL writing has a very positive effect on students' writing performance.

Writing Assessment (Electronic Feedback): previous research studies have argued that academic writing is the most significant contributing factor in students' academic success because of the heavy reliance of Omani HEIs on writing assessment requirements (Al Badwawi, 2011). Writing assessments evaluate a student's ability or performance in a writing task. Assessing writing and giving feedback for the students in HEIs is helpful in evaluating students by giving grades, placing them in suitable levels, identifying teaching methods and materials, allowing them to finish the course, evaluating progress, identifying proficiency and evaluating programmes (Dockrell et al., 2017). Instructors' feedback on writing can be either in written or electronic form (e-feedback). Instructors spend time giving extensive handwritten feedback to students who ultimately may or may not pay much attention to. However, providing e-feedback in EFL education can improve the process of learning the English language and empower EFL students to overcome their writing errors. Boyle and Hutchison (2009) argued that electronic feedback will in future be in high demand education systems because it introduces questions and tasks to assess students accurately. Accordingly, there seems to be a growing trend in the use of digital technology bringing writing drafts from paper to screen in order to provide feedback (Warschauer et al., 2013). Dikli and Bleyle, (2014) stressed that e-feedback is a quick, fair, balanced, and formative complement to instructor's traditional practice. Considering performance and attitude, Thao (2017) studied students' attitudes towards corrective feedback as well as the types of corrective feedback on their performance using questionnaires and a sample composed of 58 2nd year students and 5 English teachers. The results of the study indicated that students had a positive attitude towards teachers' corrective feedback. Besides, correction with comments and teacher correction were considered as the most useful strategies when giving feedback on learners' writing performance. Similar to corrective feedback, e-feedback also affects both students' academic writing and attitudes. Ali (2016) carried out a mixed-methods study to investigate the effect of screencast video feedback on the writing of freshmen. He studied their academic writing course and explored their attitudes towards receiving screencast feedback. The control group $(\mathrm{N}=30)$ received written comments while the experimental group $(\mathrm{N}=33)$ received video feedback to the higher order concerns of writing (content, organization and structure) and written feedback to the lower order concerns (accuracy) of their writings. The results revealed that the experimental group had higher performance than the control group in the higher order concerns of writing as well as the overall writing skill in the writing post-test. The findings also showed that the most of participants in the experimental group had positive perception of screencast feedback which they described as clear, personal, specific, supportive, multimodal, constructive, and engaging.

Critical questions remain, however, concerning the quality of corrective feedback in EFL education. John and Woll (2018) assessed the performance of VWT in comparison to Grammarly ${ }^{\circledR}$ and Microsoft ${ }^{\circledR}$ Word. The assessment of the three software applications included rates of error detection, accuracy of proposed replacement forms, and forms mistakenly flagged as incorrect. The findings showed that while inaccurate replacement forms and false alarms were relatively rare, the three software applications had poor error detection rates of less than $50 \%$. However, the findings showed that VWT and Garmmarly outperformed Microsoft Word in a wide range of grammatical errors. John and Woll (2018) recommended designing writing software that targets selecting error types. 


\subsubsection{Conventional Tutoring and Virtual Tutoring}

Learning through technology has been the core focus for researchers in language learning for the last five decades when the approaches of Computer-Assisted Language Learning (CALL), Technology-Enhanced Language Learning (TELL) and Mobile-Assisted Language Learning (MALL) took on a meaningful role in learning and teaching. The main concern of using these approaches in language education is whether technology can bring positive or negative results to college students' learning experience and whether technology-enhanced learning can facilitate foreign language learning. Previous studies in the field of language education showed that the utilization of technology dramatically influenced conventional tutoring where the instructors acted as the main and only source of knowledge. This demand of TELL requires instructors to look at conventional tutoring from a different perspective. Not ignoring the role of instructors and conventional tutoring, both language learners and instructors need to be capable of interpreting and producing texts that contain both visuals and words by teaching a new kind of "literacy" so that the instructors' role is to promote the critical analysis of such texts (Walker \& White, 2013). This literacy includes TELL which not only affects learning but also assists conventional tutors to cope with the advances of the digital age. It is argued that TELL affects how humans and learners, in particular, interact and communicate (Chen, Liu \& Wong, 2007; Murphy, 2009). The development of TELL has become inevitable over the last few decades because of the advent of new technologies and their penetration into all aspects of life. This shift in interaction has included EFL instructors who are consistently thinking of how to help language learners succeed in their learning process. Green, Brown and Robinson (2008) believe that instructors should take into consideration the fact that students are becoming more engaged in communications through different digital devices that continue to evolve at a rapid pace.

Unlike conventional tutoring, virtual tutoring is one of today's means of communication in language education. Although international and local language scholars utilize virtual tutoring differently, it has proved to have a significant impact on the learning experience. Herring et al. (2017), for instance, tested an evaluation of a computer-based approach, in which young non-verbal children with autism aged between six and nine years old responded to an on-screen "virtual tutor" through the manipulation of picture/symbol cards in two separate sessions. The findings showed that the important feature of the learning experience of non-verbal children with autism is voice type and it can influence greatly how they participate and perform in virtual tutor-led learning. In addition, to strengthen English Language reading comprehension and speaking skills in college learners, Intriago et al. (2016) employed action research to examine the use of Google Apps and Literature Circles (LCs) in virtual communities with 70 university learners for one semester. They organized 14 learning communities and learners assumed specific roles to guarantee equality of participation. The results showed an improvement in the reading comprehension and speaking skills of the participant's group. Locally, Abdallah and Mansour (2015) conducted an experimental study of 20 college learners to examine the effectiveness of implementing a Virtual Task-Based Situated Language Learning (TBSLL) environment mediated by Second Life (SL) in increasing EFL learner teachers' technological self-efficacy and their pragmatic writing skills. By administering three measurement tools; pragmatic writing skills post-test, academic self-efficacy scale and e-portfolio for formative assessment, the results showed the effectiveness of the virtual TBSLL in developing participants' pragmatic writing skills in English. Moreover, the SL teachers' technological self-efficacy was significantly higher.

Previous research studies have shown that virtual tutoring and virtual learning environments not only affect students' academic performance but also have a great influence on their attitudes towards technology. Research findings show that the use of virtual technology depends on the attitudes and experience of both teachers and learners (Fageeh, 2011). For instance, Herrera Mosquera (2017) studied the impact of employing a Virtual Learning Environment (VLE) in the EFL classroom with 210 students and 5 teachers. The instruments of the study included questionnaires, class observation notes, quick surveys, and teacher narratives. They were used to collect date related to students' perceptions and attitudes towards the use of this VLE technology in class as well as the existing conditions for such implementation. The findings showed that learners feel enthusiastic and motivated towards the use of VLEs and they suggested that instructors should indeed include them in their lessons. Nevertheless, the findings also presented some threats that could hinder the effective utilization of VLEs including the capacity of laboratories and computers, as well as Internet connectivity. Once these threats are overcome "the experience of technology-based learning turned out to be satisfactory for those EFL students" (Herrera Mosquera, 2017, p. 482). In a similar study that included 520 participants from national and international faculty members working in Saudi governmental universities, Al-Harbi, (2016) found that the faculty members have positive attitudes towards using e-tutoring technology.

Additionally, virtual tutoring has positive implications on the attitudes of EFL learners. Tan (2019), for example, investigated college students' attitudes towards business English virtual tutoring software applications and by 
using students' assessments of self-paced business English virtual tutoring software to investigate the adoption of such software applications. The simple linear regression analysis findings indicated that the majority of users of English virtual tutoring software applications felt that online sources for learning English offer greater convenience and are more effective than non-Internet resources offered in conventional tutoring.

Recently, Aiello and Mongibello (2019) designed a virtual tutoring pronunciation course to improve the oral English skills of English majors in their last year of undergraduate studies at an Italian university. The 372 students who completed all the course activities shared positive opinions and attitudes towards virtual tutoring. They indicated that they enjoyed the project, found various foci and aspects useful for their pronunciation development, and particularly appreciated the access to immediate feedback on their oral English performance. In reading skills, for instance, as an effort to improve college students' reading engagement, Park and Kim (2016) developed Virtual Tutee System (VTS) in which students take on the role of tutor and teach a virtual tutee. The results showed that the VTS group was involved in a deep level of cognitive processing when they completed the reading assignments. VTS group also exhibited superior reading performance than students in the online reading group.

More importantly, some recent studies have presented students' attitudes towards effective virtual tutoring using asynchronous tools (i.e., podcasts, videocasts, online tests, online glossary, forums, etc.) to improve English grammar. Pinto-Llorente et al. (2017) utilized VLE technology and examined students' attitudes towards some asynchronous tools to achieve the objectives of their English course. The results showed the students' positive attitudes about the efficacy of the instructional technology tools in blended-learning training to enhance their competence in grammar in English as a second language. The findings also highlighted the advantages of the e-activities, and suggest that the implemented VLE can provide an authentic learning experience through learning and practicing English grammar in real experiences and situations. Writing Pal is a virtual tutoring system designed to support writing proficiency and strategy acquisition for adult writers. Virtual pen pal writing presents automated formative feedback that provides corrective feedback strategies oriented toward student improvement of writing skills. Roscoe, et al. (2015) examined 78 High school students using a virtual pen pal to write and revise a persuasive essay each day across eight daily sessions. The findings of the linguistic properties of original and revised essays revealed that students were more likely to implement document-level revisions focused on improving elaboration, organization, and cohesion, rather than surface word-level edits focused on incorporating bigger words or less common words.

Based on the above synthesized literature, it appears that technology integration in EFL, in general, and virtual tutoring, in particular, has a great potential to eliminate the shortcomings of conventional tutoring and to provide students with autonomous learning experiences and opportunities to continuously improve their writing skills.

\section{Research Methodology}

\subsection{Research Design}

This present study employed a quasi-experimental control group design where four intact sections enrolled in a semester-long course were able to participate in the study.

\subsection{Population and Sample}

The population of the study incorporated all Year 1 students enrolled in the ENAP1002 course at College of Applied Sciences-Sohar for the academic year 2018/2019. The population consisted of 10 sections $(M=211)$.

The sample consisted of four intact groups. These were divided into two control groups $(\mathrm{N}=46)$ and two experimental $(\mathrm{N}=52)$ groups. The initial sample consisted of 98 male and female students aged 19-22 years. However, due to the fact that some students did not take the pre-test and others did not take the post-test, the actual sample size consisted of 35 in each group (Total $\mathrm{N}=70$ ) including those who completed both the pre-test and post-test. The participants' mother tongue is Arabic and they have the same social and educational background since they all completed the English Foundation Programme.

\subsection{Research Instruments}

The main research data collection instruments used in the study was the writing test and the attitude scale.

The Writing Test: To measure the impact of VWT software on writing skills, a writing test consisting of one essay question with two writing topics to choose from was developed based on the ENAP1002 test specification and the ENAP1002 course syllabus. Additionally, a rating scale for assessing writing provided by the general directorate for CASs in the Ministry of Higher Education-Oman has also been used. The adapted rating scale for assessing writing consisted of five categories; task achievement, organization, grammar, vocabulary, and 
punctuation, spelling and writing mechanics. Each category had descriptors rated out of 10 marks as follows: superior (10 marks), strong ( 8 marks), adequate (6 marks), marginal (4 marks), weak (2 mark), and not gradable (0 mark). The overall score of the writing test was 50 marks.

The Attitude Scale: Students' attitudes towards using the virtual writing tutor software to improve their academic writing skills was determined by adapting an attitude scale towards the use of instructional technologies (Metin et al., 2012). This consisted of 20 items with a five-point Likert scale.

The Validity of the Instruments: face and content validity of all the instruments were checked by a panel of area experts and practitioners, and were modified accordingly. By using Cronbach's alpha, the inter-rater reliability of the test scores was measured. The consistency of two raters was 0.93 . The reliability of the attitude scale was 0.81 based on a pilot study on 30 students from the population of the study.

\subsection{Experiment Procedures}

The aim of the quasi-experimental design in this study was to investigate students' academic performance in writing skills and their attitudes toward the VWT software. Therefore, the participants of the study were divided into two control groups and two experimental groups by the coordinator of the ENAP1002 course. Informed consent forms were distributed to the students and instructors. The experiment lasted for nine weeks in semester 2, Spring 2019. The researchers conducted an introductory session for the course coordinator and the instructors explaining the plan of the study and introducing the VWT software that instructors would use to teach the experimental groups. In Week 1, students in all of the four groups took the writing pre-test. Between Week 1and Week 9, both groups followed the same course study plan consisting of the four English language macro skills with a particular focus on the writing skills tasks and essays. The control groups followed the study plan using the conventional teaching method of paper and pencil, while the experimental groups followed the study plan using the VWT software. According to the course study plan, the students produced three essays with two drafts for each essay. In Week 9, the four groups took the writing post-test. Finally, the attitude scale was distributed to the students after the treatment.

\subsection{Features of Virtual Writing Tutor Software}

Written corrective feedback is time-consuming, thus for reasons of practicality, it is not always practical for teachers to provide extensive feedback, particularly on multiple drafts of an essay (John et al., 2017). Consequently, electronic feedback (e-feedback) that is given by online software represents an appealing alternative for a couple of reasons according to John et al. (2017). First, e-feedback not only frees up invaluable teacher time, but also helps students to develop error correction skills they can use independently. As a result, students "promote self-regulated and ubiquitous learning; rather than being reliant on a teacher, learners can access feedback autonomously, beyond the confines of the classroom" (John et al., 2017, p. 2). Second, after devoting valuable time and energy to providing written feedback on students' writing, teachers can find it frustrating to see students paying little or no consideration to their comments and corrections. Third, the immediacy of e-feedback may lead to more actions (Metcalfe, Kornell, \& Finn, 2009) on the part of the students. This is simply because students are most likely to pay attention to feedback on a composition they have just written.

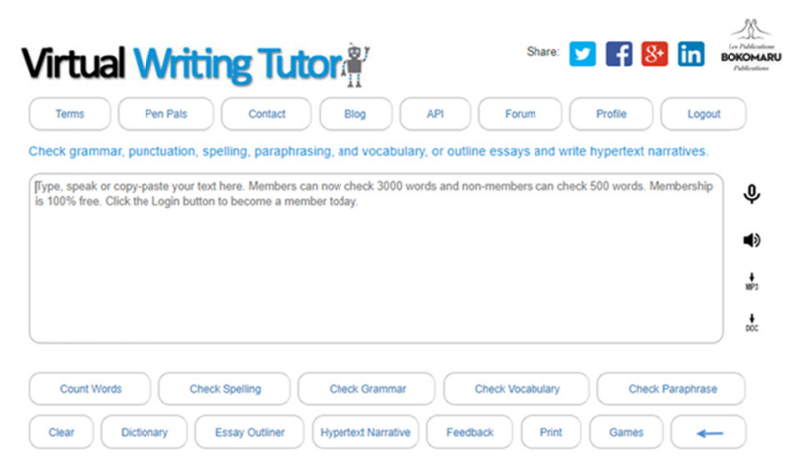

Figure 1. A screen shot of the virtual writing tutor 
Bearing the above advantages of automatic feedback in mind, the VWT software (Figure 1) is a good alternative in EFL education for students and teachers. It aims to provide English second language (ESL) learners with e-feedback on writing errors. It has a wide range of features which can be utilized in improving the writing skills of ENAP1002 students. First, it has vocabulary checker tools, academic and conversational vocabulary, clichés and power words, field-related vocabulary and target structures. In addition, it has some other features such as a grammar checker, spelling and punctuation checker, paraphrase checker and essay checker. Finally, it has a word counter, essay outliner, feedback and links (Figure 2), error correction game, grammar checking and incorporation to ESL courses. Bearing these features in mind, EFL learning and teaching in HEIs has great opportunities to utilize modern technological trends to allow for high-quality learning experience.

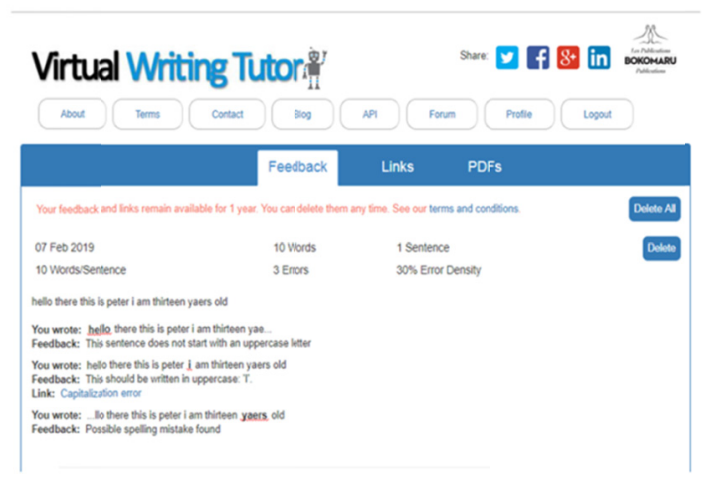

Figure 2. A screen shot of the VWT Feedback and links

\section{Results and Discussion}

\subsection{Results Relating Research Question 1}

To answer the Research Question 1 about the effect of the VWT software on the performance of Year 1 students in terms of writing skills, two main types of statistical analysis were used. In order to compare the performance of the control and experimental group before and after the introduction of VWT software, an independent sample t-test was conducted and the results are shown in Table 1 and Table 2.

Table 1. Independent sample $t$ test for the mean scores of the pre-test*

\begin{tabular}{llllllll}
\hline Pre-test & Group & N & Mean & Std. Deviation & df & t & Sig. (2-tailed) \\
\cline { 2 - 6 } & Control & 35 & 17.86 & 3.30 & \multirow{2}{*}{68} & .67 & .503 \\
\cline { 2 - 6 } & Experimental & 35 & 17.31 & 3.43 & & & \\
\hline
\end{tabular}

$*$ Total score $=50$

An independent sample t-test was used to check the equivalence between the control and experimental groups before the treatment, $\mathrm{t}(68)=.67, \mathrm{p}=.50$ which indicates that there is no significant difference between the control group $(\mathrm{M}=17.31, \mathrm{SD}=3.30)$ and the experimental group $(\mathrm{M}=17.86, \mathrm{SD}=3.43)$.

Table 2. Independent sample $t$ test for the mean scores of the post-test*

\begin{tabular}{llllllll}
\hline Post-test & Group & N & Mean & Std. Deviation & df & t & Sig. (2-tailed) \\
\cline { 2 - 6 } & Control & 35 & 18.34 & 2.56 & \multirow{2}{*}{68} & 3.67 & .000 \\
\cline { 2 - 5 } & Experimental & 35 & 20.51 & 2.36 & & & \\
\hline
\end{tabular}

*Total score $=50$ 
An independent sample t-test was calculated to check the effect of the VWT software on the writing skills, $\mathrm{t}(68)$ $=3.67, \mathrm{p}=.000$ with VWT software indicating a larger effect on the experimental group $(\mathrm{M}=20.51, \mathrm{SD}=2.36)$ than the control group $(\mathrm{M}=18.34, \mathrm{SD}=2.56)$. The Cohen's $d$ effect size was $(0.88)$ which indicates large effect size according to Cohen's (1988) three levels; small 0.20, medium 0.50 and large .80 .

In order to compare the performance of the experimental group before and after the introduction of VWT software, a paired sample t-test was conducted the results are shown in Table 3.

Table 3. Paired samples t-test for the mean scores of the experimental group*

\begin{tabular}{llllllll}
\hline \multirow{2}{*}{$\begin{array}{l}\text { Experimental } \\
\text { Group }\end{array}$} & Test & $\mathrm{N}$ & Mean & Std. Deviation & $\mathrm{df}$ & $\mathrm{t}$ & Sig. (2-tailed) \\
\cline { 2 - 7 } & Pre-test & 35 & 35.71 & 6.61 & \multirow{2}{*}{4.13} & .000 \\
\cline { 2 - 6 } & Post-test & 35 & 41.03 & 4.73 & & & \\
\hline
\end{tabular}

$*$ Total score $=50$

A paired sample t-test was used for the experimental group to check the effect of the software on the writing skills, $\mathrm{t}(34)=4.13, \mathrm{p}=.000$ with VWT software indicating there is a larger effect on the experimental group after the treatment $(\mathrm{M}=41.03, \mathrm{SD}=4.73)$ than the effect before the treatment $(\mathrm{M}=35.71, \mathrm{SD}=6.61)$. In order to measure the size effect, Cohen's $d$ was calculated for the experimental group before $(\mathrm{M}=35.71, \mathrm{SD}=6.61)$ and after the treatment $(\mathrm{M}=41.03, \mathrm{SD}=4.73)$ and was found to be $(0.92)$ which indicates large size effect according to Cohen's (1988) three levels; small 0.20 , medium 0.50 and large 0.80 . This indicates that the VWT positively affected the writing skills of Year 1 students.

Cohen-Gross (2003) suggested that academic writing skills are among the best predictors of success during the first year of college or university. The positive results of the effect of the VWT software on the writing skills of Year 1 students seem to be in line with previous research studies (Al Badwawi, 2011; Ellis et al., 2007; Cetto, 2010; Blake, 2016; Hwang et al., 2016; Dikli \& Bleyle, 2014) that emphasized the role instructional technology plays in academic writing. The findings of the current study agree with the previous findings related to using instructional technology to enhance EFL learning in general and writing skills in particular. Similarly, reviewed literature in EFL education (Xu et. al, 2018; Chun, 2016; Rosen, 2016; James, 2016; Abdallah \& Mansour, 2015; Eder Intriago et al., 2016) found that various technological tools and trends had a positive impact on students' EFL learning generally and academic writing specifically. Added to that, the findings are also consistent with previous studies investigating virtual tutoring to improve education in general and EFL learning in particular (Tan, 2019; Abdelmageed \& El-Naggar, 2018; Thao, 2017; Ali, 2016; Park \& Kim, 2016).

However, this study contradicted the findings of Jayaron and Abidin (2016) that measured the impact of forum discussions on students' linguistic complexity in writing skills and found no statistical difference between the groups' writing performance. It also disagreed with Hwang et al. (2016) who identified that control and experimental groups were equal on the listening post-test when investigating the feasibility of mobile game-based learning activities. This disagreement might be due to different contexts, different instructional technology (treatment), different sample sizes or instructional materials.

Overall, these studies are similar to the current study in several aspects including integrating technological trends in EFL education, virtual trends (virtual tutoring, virtual communities, virtual learning environments), quasi-experimental research design, research instruments, sample size and statistical analysis of the collected data.

\subsection{Results Relating Research Question 2}

To answer Research Question 2 about the attitudes of the students towards the use of VWT for improving their writing skills, descriptive statistics of means and standard deviations were applied for the attitude scale. The overall mean score and standard deviation are shown in Table 4. 
Table 4. Descriptive statistics of students' attitude towards VWT Software

\begin{tabular}{|c|c|c|}
\hline Statement & Mean & Std. Deviation \\
\hline 1. I enjoy using VWT in the writing class. & 4.29 & .78 \\
\hline 2. I feel that the usage of VWT increases the accuracy of my writing. & 4.37 & .49 \\
\hline 3. I learn writing better when I use VWT rather than just with paper and pencil. & 3.69 & .99 \\
\hline 4. I feel motivated to use VWT to help proofread my essay writing. & 3.94 & .93 \\
\hline 5. I am bored when the VWT is used in writing class. & 3.80 & 1.13 \\
\hline 6. I am not interested in using VWT in the class. & 4.14 & .77 \\
\hline 7. I face difficulty in using VWT in writing my essays. & 3.91 & 1.04 \\
\hline 8. I dislike using VWT in the writing classes. & 3.66 & .96 \\
\hline 9. I feel more comfortable in the classes that use VWT. & 3.69 & .86 \\
\hline 10. I become more active in the classes using VWT. & 3.80 & .67 \\
\hline 11. I remember the content easily in writing lessons when VWT is used. & 3.63 & .77 \\
\hline 12. The writing skills learnt by using VWT are more permanent. & 3.63 & .77 \\
\hline 13. My creativity increases in lessons when VWT is used. & 3.80 & .83 \\
\hline 14. VWT helps me edit my grammar, spelling and vocabulary. & 4.34 & .76 \\
\hline 15. Usage of VWT in writing essays is necessary & 3.74 & .98 \\
\hline 16. It is a waste of time to use VWT in writing classes. & 4.03 & .98 \\
\hline 17. I lose my concentration in the writing lesson using VWT. & 3.80 & .96 \\
\hline 18. I avoid using VWT in my writing classes. & 3.69 & 1.23 \\
\hline 19. It is beneficial for me to use the VWT in writing my essays. & 4.14 & .64 \\
\hline 20. Usage of the VWT should be made more prevalent in writing classes. & 3.77 & .77 \\
\hline Total Mean & 3.89 & .39 \\
\hline
\end{tabular}

The attitude scale consisted of 20 statements to measure the EFL learners' attitude towards VWT. The overall mean score was $(\mathrm{M}=3.89, \mathrm{SD}=0.39)$ which represents students' positive attitude towards using VWT to improve their writing skills. However, there were some statements that obtained lower and higher mean scores than others as shown in Table 5 and Table 6.

Table 5. Descriptive statistics of the statements with the lowest mean scores in the attitude scale

\begin{tabular}{lll}
\hline Statement & Mean & Std. Deviation \\
\hline 12. The writing skills learnt by using VWT are more permanent & 3.63 & .77 \\
\hline 11. I remember the content easily in writing lessons when VWT is used. & 3.63 & .77 \\
\hline 8. I dislike using VWT in the writing classes. & 3.66 & .96 \\
\hline
\end{tabular}

Statements 12, 11 and 8 in the attitude scale received the lowest mean scores of the 20 statements. The lowest mean scores ranged between $(\mathrm{M}=3.63, \mathrm{SD}=0.77)$ and $(\mathrm{M}=3.66, \mathrm{SD}=0.96)$. Statements 12 and 11 represented the students' attitude towards retention of the content learned via VWT while Statements 8 represented students' attitude towards using VWT in writing classes. 
Table 6. Descriptive statistics of the statements with the highest mean scores in the attitude scale

\begin{tabular}{lll}
\hline Statement & Mean & Std. Deviation \\
\hline 2. I feel that the usage of VWT increases the accuracy of my writing. & 4.37 & .49 \\
\hline 14. VWT helps me edit my grammar, spelling and vocabulary & 4.34 & .76 \\
\hline 1. I enjoy using VWT in the writing class. & 4.29 & .78 \\
\hline
\end{tabular}

Statements 2, 14 and 1 in the attitude scale received the highest mean scores out of the 20 statements. The highest mean scores ranged between $(\mathrm{M}=4.37, \mathrm{SD}=0.49)$ and $(\mathrm{M}=4.29, \mathrm{SD}=0.78)$. Statements 2 and 14 concerned the accuracy and editing of grammar, spelling and vocabulary while Statement 1 concerned the positive attitude towards the VWT software. These statements agree with the positive results of Research Question 1 about the students' performance in the post-writing test. This indicates that Year 1 students had a positive attitude towards the VWT software.

The findings of the attitude scale indicate participants have a positive attitude towards using VWT software in the writing classes. Year 1 students enjoyed using the VWT software and found it beneficial and helpful in checking the accuracy of their essays including spelling, punctuation, grammar and vocabulary. Generally speaking, the positive results of the students' attitude towards using VWT software are consistent with the positive findings of previous studies that investigated students' attitudes towards instructional technology. Examples of those research studies are Ellis et al., (2007); Aljumah, (2012); Hwang et al., (2016); Herrera Mosquera, (2017); Metin, et al., (2012); Khan, et al., (2018) and Orgaz et al. (2018).

As for virtual tutoring, the findings of students' attitudes towards using it are in line with the positive results of previous studies investigating English courses (Mosquera, 2017; Tan, 2019), reading skills (Park \& Kim, 2016), pronunciation (Aiello \& Mongibello, 2019), grammar skills (Pinto-Llorente et al., 2017), and writing skills (John et al., 2017; Roscoe, et al., 2015). Added to that, the results are also consistent with the previous positive findings of the e-feedback in EFL education such as Thao (2017) and Ali (2016). However, the findings of this study contradicted what Baturay et al. (2017) found in that computer ownership, Internet access and the amount of daily computer use do not correlate with attitudes towards instructional technology.

Finally, although students had positive attitudes towards the use of VWT software and found it to be helpful in improving the accuracy of their essay writing, the statements with the lowest mean scores reflected some critical concerns regarding the content and retention of the information learnt with the assistance of the VWT software. This might be due to the lack of specific contextualized content provided by VWT software designers for international EFL learners.

\section{Conclusion}

The findings of this study suggest that the emerging Virtual Tutoring technologies appear to be a viable and appealing alternative for English language learning in general, and writing in particular. Apparently, these technologies, such as VWT have shifted the conventional art of personal tutoring to a more reliable form of e-feedback that can be provided in both synchronous and asynchronous learning environments. Consequently, VWT not only frees up invaluable teacher time, but also helps students to develop error correction skills that can be used independently, which in turns, may promote self-regulated and ubiquitous learning. It is believed that the findings of this study can provide valuable insights for EFL instructors and those in other disciplinary areas to better integrate similar emerging technologies that enhance both teaching and students' learning experiences. Accordingly, further research is needed to examine the various attributes of the VWT software such as the pen pal feature on a wider range of students' academic writing experience in a more longitudinal and large-scope studies.

\section{References}

Abdallah, M. M. S., \& Mansour, M. M. (2015). Virtual task-based situated language-learning with second life: developing EFL pragmatic writing and technological self-efficacy. Arab World English Journal, 150-182. https://doi.org/10.2139/ssrn.2843987

Abdelmageed, M., \& El-Naggar, Z. (2018). Digital Storytelling Enhances Students' Speaking Skills at Zewail University of Science and Technology in Egypt. Society for Information Technology \& Teacher Education International Conference (pp. 278-287). Association for the Advancement of Computing in Education (AACE). 
Adnan, Z. (2009). Some Potential Problems for Research Articles Written by Indonesian Academics when Submitted to International English Language Journals. Asian EFL Journal, 11(1), 107-125.

Aiello, J., \& Mongibello, A. (2019). Supporting EFL learners with a Virtual Environment: A Focus on L2 Pronunciation. Journal of E-Learning and Knowledge Society, 15(1), 83-94.

Al Naibi, I., Al-Jabri, M., \& Al-Kalbani, I. (2018). Promoting learners' paragraph writing using EDMODO: An action research. TOJET, 17(1), 130-143.

Al-Badwawi, H. S. (2011). The perceptions and practices of first year students' academic writing at the colleges of applied sciences in Oman. Leeds: University of Leeds.

Al-Harbi, M. (2016). Faculty attitudes toward and motivation for Virtual Learning Environments (VLE) for language studies: A cross-national study in Saudi Arabian universities. Journal of Psychology and Behavioral Science, 4(2), 100-114. https://doi.org/10.15640/jpbs.v4n2a9

Ali, A. D. (2016). Effectiveness of using screencast feedback on efl students' writing and perception. English Language Teaching, 9(8), 106-121. https://doi.org/10.5539/elt.v9n8p106

Al-Issai, N. (2012). A Speculation on writing assessment issues in Colleges of Applied Sciences in Oman. Social and Behavioral Sciences, 69, 739-744. https://doi.org/10.1016/j.sbspro.2012.11.468

Aljumah, F. H. (2012). Saudi learner perceptions and attitudes towards the use of blogs in teaching English writing course for EFL majors at Qassim University. English Language Teaching, 5(1), 100-116. https://doi.org/10.5539/elt.v5n1p100

Al-Motairi, M. (2013). Investigating Kuwaiti teachers' and head teachers' attitudes towards inclusion. Doctoral dissertation, University of Birmingham.

Altun, M. (2015). The integration of technology into foreign language teaching. International Journal on New Trends in Education and Their Implications, 6(1), 22-27.

Atashian, S., \& Al-Bahri, K. (2018). Towards Arab Learners' Grammatical Errors in Academic Writing \& their Perceptions. Arab World English Journal, 140-145. https://doi.org/10.24093/awej/MEC1.10

Bacha, N. N. (2002). Developing learners' academic writing skills in higher education: A study for educational reform. Language and Education, 16(3), 161-177. https://doi.org/10.1080/09500780208666826

Bacha, N. N., \& Bahous, R. (2008). Contrasting views of business students' writing needs in an EFL environment. English for Specific Purposes, 27(1), 74-93. https://doi.org/10.1016/j.esp.2007.05.001

Barbera, E. (2009). Mutual feedback in e-portfolio assessment: an approach to the netfolio system. British Journal of Educational Technology, 40(2), 342-357. https://doi.org/10.1111/j.1467-8535.2007.00803.x

Baturay, M. H., Gökçearslan, Ş., \& Ke, F. (2017). The relationship among pre-service teachers' computer competence, attitude towards computer-assisted education, and intention of technology acceptance. International Journal, Technology Enhanced Learning, 9(1), 1-13. https://doi.org/10.1504/IJTEL.2017.084084

Beale, R., \& Sharples, M. (2002). Design guide for developers of educational software. British Educational Communications and Technology Agency.

Bernacki, M. L., Aguilar, A. C., \& Byrnes, J. P. (2011). Self-regulated learning and technology-enhanced learning environments: An opportunity propensity analysis. In G. Dettori, \& D. Persico (Eds.), Fostering Self-Regulated Learning through ICT. New York: Information Science Reference.

Blake, R. (2016). Technology and the four skills. Language Learning \& Technology, 20(2), 129-142.

Boyle, A., \& Hutchinson, D. (2009). Sophisticated tasks in e-assessment: What are they and what are their benefits? Assessment \& Evaluation in Higher Education, 34(3), 305-319. https://doi.org/10.1080/02602930801956034

Carvalho, E. S., \& Seixas, S. (2018). Virtual tutoring. Hands-on Science, Advancing Science, Improving Education.

Chen, Y., Liu, C., \& Wong, R. (2007). The adoption of synchronous and asynchronous media in the teaching of a second language. Issues in Information Systems, 7(1), 217-223. Retrieved from https://bit.ly/2LF28xr

Chun, D., Kern, R., \& Smith, B. (2016). Technology in language use, language teaching, and language learning. The Modern Language Journal, 100(S1), 64-80. https://doi.org/10.1111/modl.12302

Cohen, J. (1988). Statistical power analysis for the behavioral sciences (2nd ed.). Hillsdale, NJ Lawrence 
Erlbaum Associates, Publishers.

Cohen-Gross, D. (2003). Teaching writing in educational systems worldwide-trends and goals. Chelkat Lashon, $35,65-75$.

Creswell, J. W. (2012). Educational research: Planning, conducting, and evaluating quantitative and qualitative research (4th ed.). Boston: Pearson Education.

Denton, P., Madden, J., Roberts, M., \& Rowe, P. (2008). Students' response to traditional and computer-assisted formative feedback: A comparative case study. British Journal of Educational Technology, 39(3), 486-500. https://doi.org/10.1111/j.1467-8535.2007.00745.x

Dikli, S., \& Bleyle, S. (2014). Automated Essay Scoring feedback for second language writers: How does it compare to instructor feedback?. Assessing Writing, 22, 1-17. https://doi.org/10.1016/j.asw.2014.03.006

Dockrell, J., Connelly, V., Walter, K., \& Critten, S. (2017). The Role of Curriculum Based Measures in Assessing Writing Products. In Writing development in struggling learners (pp. 182-197). Brill. https://doi.org/10.1163/9789004346369_011

Ellis, R. (2004). University student approaches to learning science through writing. International Journal of Science Education, 26(15), 1835-1853. https://doi.org/10.1080/0950069042000243772

Ellis, R. A., Taylor, C. E., \& Drury, H. (2007). Learning science through writing: associations with prior conceptions of writing and perceptions of a writing program. Higher Education Research \& Development, 26(3), 297-311. https://doi.org/10.1080/07294360701494310

Ezer, H., Margolin, B., \& Sagi, R. (2009). Academic writing: Perceptions among education students and lecturers of its significance and role in a college of education, Research Report. Tel Aviv: Research \& Development Authority, Levinsky College of Education.

Fageeh, A. (2011). EFL students' readiness for e-learning: factors influencing e-learners' acceptance of the Blackboard in a Saudi university. The Jaltcall Journal, 7(1), 19-42. https://doi.org/10.29140/jaltcall.v7n1.106

Flower, L., \& Hayes, J. R. (1981). A Cognitive Process Theory of Writing. College Composition and Communication, 32(4), 365-387. https://doi.org/10.2307/356600

Flowerdew, J., \& Peacock, M. (2001). Research perspectives on English for academic purposes Cambridge. Cambridge University Press. https://doi.org/10.1017/CBO9781139524766

Fraenkel, J. R., \& Wallen, N. E. (2009). How to design and evaluate research in education (7th ed.). New York: McGraw-Hill.

George, D., \& Mallery, M. (2003). Using SPSS for Windows step by step: a simple guide and reference. Allyn, Bacon, Boston.

Godwin-Jones, R. (2015). Contributing, creating, curating: Digital literacies for language learners. Language Learning \& Technology, 19(3), 8-20.

Green, T. D., Brown, A., \& Robinson, L. (2008). Making the most of the web in your classroom: a teacher's guide to blogs, podcasts, wikis, pages and sites. Thousand Oaks: Corwin.

Haines, K. (2016). Expanding the knowledge base of teachers' use of communication tools for language learning. System, 62, 102-112. https://doi.org/10.1016/j.system.2016.07.008

Harris, B. R., Lindner, R. W., \& Pina, A. A. (2011). Strategies to promote self-regulated learning in online environments. In G. Dettori, \& D. Persico (Eds.), Fostering Self-regulated learning through ICT. New York: Premier Reference Source.

Hayes, J. R. (2012). Modeling and remodeling writing. Written Communication, 29, $369-388$. https://doi.org/10.1177/0741088312451260

Healey, D. (2018). TESOL technology standards. The TESOL Encyclopedia of English Language Teaching, 1-6. https://doi.org/10.1002/9781118784235.eelt0453

Herring, P., Kear, K., Sheehy, K., \& Jones, R. (2017). A virtual tutor for children with autism. Journal of Enabling Technologies, 11(1), 19-27. https://doi.org/10.1108/JET-01-2016-0006

Huang, Y. N., \& Hong, Z. R. (2016). The effects of a flipped English classroom intervention on students' information and communication technology and English reading comprehension. Educational Technology Research and Development, 64(2), 175-193. https://doi.org/10.1007/s11423-015-9412-7 
Hwang, W. Y., Shih, T. K., Ma, Z. H., Shadiev, R., \& Chen, S. Y. (2016). Evaluating listening and speaking skills in a mobile game-based learning environment with situational contexts. Computer Assisted Language Learning, 29(4), 639-657. https://doi.org/10.1080/09588221.2015.1016438

Hyland, K. (2009). Teaching and researching writing (2nd ed.). London: Pearson Education.

Hyland, K., \& Hamp-Lyons, L. (2002). EAP: issues and directions. Journal of English for Academic Purposes, 1(1), 1-12. https://doi.org/10.1016/S1475-1585(02)00002-4

Intriago, E., Villafuerte, J. S., Jaramillo, M. A. M., Lema, A., \& Echeverria, J. (2016). Google apps for virtual learning communities development: strengthening English language skills in a university environment. AtoZ: Novas Práticas Em Informação E Conhecimento, 5(1), 21-32. https://doi.org/10.5380/atoz.v5i1.45170

James, J. (2016). ICT Integration in Academic Writing: An Experiment in Blended Learning. Arab World English Journal, 7(3), 320-339. https://doi.org/10.24093/awej/vol7no3.24

Jayaron, J., \& Abidin, M. J. Z. (2016). A pedagogical perspective on promoting English as a foreign language writing through online forum discussions. English Language Teaching, 9(2), 84-101. https://doi.org/10.5539/elt.v9n2p84

John, P., Woll, N., Gazaille, M., \& Cardoso, W. (2017, April). Using grammar checkers to provide written corrective feedback. Paper presented at the 6th Meeting on Language Teaching (MeLT/ReEL), Montréal, Québec, Canada. Retrieved from https://bit.ly/2SnB6tv

Khan, M. S., Ali, F., Mustafa, G., \& Farooqi, S.-U.-H. (2018). Effectiveness of an educational software system (Desire2Learn) in teaching English grammar. Arab World English Journal (AWEJ) Special Issue on CALL Number, 4, 144-159. https://doi.org/10.24093/awej/call4.11

Kongsuebchart, J., \& Suppasetseree, S. (2016). A weblog-based electronic portfolio to improve English writing skills of Thai EFL undergraduate students. Learning in and beyond the Classroom: Ubiquity in Foreign Language Education, 148-158.

Kramsch, C. (2009). The multilingual subject: What foreign language learners say about their experience and why it matters. Cambridge, UK: Cambridge University Press.

Lassault, J., \& Ziegler, J. C. (2018). Digital tools to support the acquisition of reading skills. Langue Francaise, (199), 111. https://doi.org/10.3917/lf.199.0111

Leki, I. (2007). Undergraduates in a second language: Challenges and complexities of academic literacy development. New York: Lawrence Erlbaum Associates.

Manchón, R. A., \& Larios, J. (2007). Writing-to-learn in instructed language learning contexts. Intercultural Language Use and Language Learning, 101-121. https://doi.org/10.1007/978-1-4020-5639-0_6

Matsuda, P. K. (2003). Process and post-process: A discursive history. Journal of Second Language Writing, 12(1), 65-83. https://doi.org/10.1016/S1060-3743(02)00127-3

McMillan, J. H., \& Wergin, J. F. (2002). Understanding and evaluating educational research. Upper Saddle River, New Jersey: Merrill Prentice Hall.

Metcalfe, J., Kornell, N., \& Finn, B. (2009). Delayed versus immediate feedback in children's and adults' vocabulary learning. Memory \& Cognition, 37(8), 1077-1087. https://doi.org/10.3758/MC.37.8.1077

Metin, M., Yilmaz, G. K., Coskun, K., \& Birisci, S. (2012). Developing an attitude scale towards using instructional technologies for pre-service teachers. Turkish Online Journal of Educational Technology-TOJET, 11(1), 36-45.

Ministry of Higher Education. (2019, May 5). Private HEIs in Oman. Retrieved from https://www.mohe.gov.om/InnerPage.aspx?id=9767b8ed-876e-4dfc-9707-c2c3e337c078

Murphy, E. (2009). Online synchronous communication in the second-language classroom. Canadian Journal of Learning and Technology, 35(3). https://doi.org/10.21432/T2KG6C

Myhill, D., \& Watson, A. (2011). Teaching writing. In A. Green (Ed.), Becoming a reflective English teacher. Berkshire, England: Open University Press, McGraw-Hill.

Nayar, P. B. (1997). ESL/EFL dichotomy today: Language politics or pragmatics?. TESOL Quarterly, 31, 9-37. https://doi.org/10.2307/3587973

Odera, F., \& Ogott, G. (2014). Use of technological resources in the acquisition of language skills in early childhood development and education programmes in Gem Sub-County, Kenya. International Journal of 
Academic Research in Progressive Education and Development, 3(4), 1-13. https://doi.org/10.6007/IJARPED/v3-i4/958

Orgaz, F., Moral, S., \& Domínguez, C. M. (2018). Student's attitude and perception with the use of technology in the university. Journal of Educational Psychology-Propositos y Representaciones, 6(2), $277-299$. https://doi.org/10.20511/pyr2018.v6n2.230

Park, S. W., \& Kim, C. (2016). The effects of a virtual tutee system on academic reading engagement in a college classroom. Educational Technology Research and Development, 64(2), 195-218. https://doi.org/10.1007/s11423-015-9416-3

Pinto-Llorente, A. M., Sánchez-Gómez, M. C., García-Peñalvo, F. J., \& Casillas-Martin, S. (2017). Students' perceptions and attitudes towards asynchronous technological tools in blended-learning training to improve grammatical competence in English as a second language. Computers in Human Behavior, 72, $632-643$. https://doi.org/10.1016/j.chb.2016.05.071

Reichelt, M. (2001). A Critical Review of Foreign Language Writing Research on Pedagogical Approaches. The Modern Language Journal, 85(4), 578-598. https://doi.org/10.1111/0026-7902.00127

Robson, C. (2002). Real World Research. Oxford: Blackwell. https://doi.org/10.1016/S0262-1762(02)80276-0

Roscoe, R. D., Snow, E. L., Allen, L. K., \& McNamara, D. S. (2015). Automated detection of essay revising patterns: Applications for intelligent feedback in a writing tutor. Grantee Submission, 10(1), 59-79.

Rosen, D. J. (2016). Websites for Assessing Writing. Journal of Research and Practice for Adult Literacy. Secondary, and Basic Education, 5(1), 89.

Sauro, S. (2014). Lessons from the fandom: Task models for technology-enhanced language learning. In M. González-Lloret, \& L. Ortega (Eds.), Technology-mediated TBLT: Researching technology and tasks (pp. 239-262). Philadelphia, PA: John Benjamins. https://doi.org/10.1075/tblt.6.09sau

Shadish, W. R., Cook, T. D., \& Campbell, D. T. (2002). Experimental and quasi-experimental designs for generalized causal inference. Boston: Houghton-Mifflin.

Shrestha, P., \& Coffin, C. (2012). Dynamic assessment, tutor mediation and academic writing development. Assessing Writing, 17(1), 55-70. https://doi.org/10.1016/j.asw.2011.11.003

Sligar, S. R., Pelletier, C. D., Bonner, H. S., Coghill, E., Guberman, D., Zeng, X., ... Dennis, A. (2017). Student perceptions of online tutoring videos. New Horizons in Adult Education and Human Resource Development, 29(4), 4-19. https://doi.org/10.1002/nha3.20196

Sokolik, M. (2003). Writing. In D. Nunan (Ed.), Practical English language teaching (pp. 87-108). New York: McGraw-Hill.

Thao, N. T. T. (2017). Teachers'corrective feedback on English students'writing. European Journal of English Language Teaching, 2(1), 177-197.

Urquhart, V. (2006). Examining 4 myths about learning to teach writing. The Learning Professional, 27(3), 30-35.

Walker, A., \& White, G. (2013). Technology Enhanced Language Learning. Connecting Theory and Practice. Oxford, UK: Oxford University Press.

Warschauer, M. (2013). Technological change and the future of CALL. In New perspectives on CALL for second language classrooms (pp. 27-38). Routledge.

Xu, Z., Banerjee, M., Ramirez, G., Zhu, G., \& Wijekumar, K. (2018). The effectiveness of educational technology applications on adult English language learners' writing quality: a meta-analysis. Computer Assisted Language Learning, 1-31. https://doi.org/10.1080/09588221.2018.1501069

\section{Copyrights}

Copyright for this article is retained by the author(s), with first publication rights granted to the journal.

This is an open-access article distributed under the terms and conditions of the Creative Commons Attribution license (http://creativecommons.org/licenses/by/4.0/). 